\title{
PRIVATE PLACEMENTS AND SECONDARY TRANSACTIONS: THE WHEAT REPORT PROPOSALS FOR REFORM
}

\begin{abstract}
HUGH L. Sowards*
The Securities Acts Amendments of $1964^{1}$ have been described as "the most significant statutory advance in federal securities regulation and investor protection since 1940...."2 Of practical importance to attorneys serving corporate clients was the fact that, for the first time, many of those clients were subjected to the registration and reporting requirements of the federal securities laws. ${ }^{3}$ A major objective of the 1964 Amendments was "to afford investors in publicly-held companies whose securities are traded over-the-counter the same fundamental disclosure protections as have been provided to investors in companies whose securities are listed on an exchange." 4
\end{abstract}

* Professor of Law, University of Miami. B.S. 1941, Trinity College; LL.B. 1946, Yale University.

1. 15 U.S.C. $\S \S 77 d, 78 c$ (Supp. IV, 1969).

2. SEC News Digest No. 64-9-9 (Sept. 14, 1964).

3. Securities Act of 1933, 15 U.S.C. 77a-aa (1964) [hereinafted cited as the 1933 Act]; Securities Exchange Act of 1934, 15 U.S.C. $\$ \S 78$ a-ji (1964) [hereinafter cited as the 1934 Actl.

Until 1964, registration and reporting protection afforded by seetions 12 and 13 of the 1934 Act was available only to persons who owned securities registered on a national securities exchange. Companies whose securities had not been registered under the 1933 Act but which were traded in the over-the-counter market were not subject to the registration and reporting requirements of sections 12 and 13. Section 15(d) of the 1934 Act, enacted in 1936, did provide

: that under certain circumstances the reporting requirements of section 13 were applicable to unlisted companies whieh filed registration statements under the 1933 Act. These so-called "15(d) companies" and their status under the reporting requirements provided investor proteetion in the over-the-eounter market on a fragmentary basis only.

Enactment of the 1964 Amendments provided in effect that companies whose securities are registered pursuant to seetion 12 of the 1934 Aet are subjeet to the periodic reporting requirements of section 13, by the filing of sueh Forms as 8-K, 9-K, and 10-K, and the proxy rules under section 14 . In this connection, eompanies whose securities must be registered under section 12 are (1) companies whose securities are listed on national securities exchanges, and (2) companies engaged in interstate commerce, having total assets exceeding $\$ 1$ million and a class of equity securities held of record by 500 or more persons. In addition to these companies, certain other companies are subject to the periodic reporting, but not to the proxy, requirements of section 14. These companies include issuers that have filed a registration statement which has become effeetive under the 1933 Act. 15 U.S.C. $\$ 77$ d (Supp. IV, 1969).

4. S. REP. No. 379, 88th Cong., 1st Sess. 9-10 (1963). "There is no convincing reason why the comprehensive scheme of disclosure that affords protection to investors in the exchange markets should not also apply to the over-the-counter market .... The public should not be asked to buy and sell in darkness." Id. 
This elimination of the double standards of disclosure for listed and unlisted companies has made it practicable for the Securities and Exchange Commission to re-examine its disclosure policies and to increase investor protection significantly through its rule-making power within the framework of existing legislation. The Commission is currently doing exactly that by implementing some of the recommendations made in the Wheat Report. ${ }^{5}$ Adoption of these recommendations will represent sweeping changes from the standpoint of securities attorneys and the advice they give to corporate and individual clients, especially in that area of securities regulation concerned with private placements and secondary transactions.

\section{Private Placements and Secondary Transactions}

A central feature of the Wheat Report is its attempt to extend maximum protection to investors in the trading markets through closer coordination between the disclosure requirements of the 1933 and 1934 Acts. ${ }^{6}$ The heart of the Report is concerned with secondary transactions by persons who acquired their securities in non-public transactions. ${ }^{7}$ More particularly, the Report seeks to achieve a greater degree of certainty and predictability with respect to when

5. Staff, Securities and Exchange Commission, Disclosure to Investors, A Reappraisal of Federal Administrative Poldcies UNder the '33 ANd '34 ACTs (1969) [hereinafter cited as WHEAT REPORT]. The Commission release implementing that segment of the Report dealing with private placements and secondary transactions is Securities Act Ro. lease No. 4997 (Sept. 15, 1969). For a general discussion of the Wheat Report, see Sowards, The Wheat Report and Reform of Federal Securities Regulation, 23 VAND. L. REV. 495 (1970).

6. See Wheat, The Disclosure Policy Study of the SEC, 24 Bus. LAw. 33 (1968).

7. WhEAT RePORT ch. VI. It is beyond the scope of this article to examine in detail the existing criteria for distinguishing between public and private offerings. The main point, of course, is that if private purchasers are merely conduits and take "with a view to distribution" within the mcaning of section 2(11) of the 1933 Act, they are statutory "underwriters." Moreover, the issuing company in such instances is exposed to the risk of violation of the registration requirements of the Act with attendant civil liabilities. See SEC Securities Act Release No. 4445 (Feb. 2, 1962). Leading cases setting forth criteria for determining the public or private character of the offering include SEC v. Ralston Purina Co., 346 U.S. 119 (1953); Gilligan, Will * Co. v. SEC, 267 F.2d 461 (2d Cir. 1959). See also United States v. Sherwood, 175 F. Supp. 480 (S.D.N.Y. 1959); Crowell-Collier Publishing Co., SEC Securities Act Release No. 3825 (Aug. 12, 1957); SEC Securities Act Release No. 4552 (Nov. 6, 1962) (discussing four principal factors: (1) the number of offeres and their relationship to cach other and the issuer; (2) the number of units offered; (3) the sizc of the offering; (4) the type and manner of the offering); C. Israels, SEC Problems of Controlling Shareholders AND IN UNDERWRITINGS 30-31 (1962); Victor \& Bedrick, Private Offering: Hazards for the Unwary, 45 VA. L. REV. 869 (1959). 
registration under the 1933 Act is required for resale of securities acquired in private offerings. Broadly stated, this objective is accomplished by the commendable. recommendation, long overdue, that existing subjective tests used by the Commission governing resale of such securities be replaced by objective tests. Put another way, under the rules proposed by the Report, which, if adopted, will take effect prospectively, the private purchaser's "inner thoughts" would no longer be a factor in a later attempt to ascertain his "investment intent" at the time of acquisition. The mirror of his mind as reflected by such nonsensical criteria as a subsequent change in his circumstances and "fungibility" would be discarded and replaced by the practical and workable tests of time of holding and, in certain instances, by the number and identity of the private holders.

In recommending this substitution of objective for subjective criteria, the Report emphasizes that investor protection can be attained only if distinctions are made between reporting and nonreporting companies. This stems from the premise that investors in the trading markets can make better informed investment decisions if the securities to be bought or sold are those of companies subject to the 1934 Act registration and reporting requirements. They need not "buy and sell in darkness,"8 for current information would be available to them under improved reporting requirements providing for continuing sources of disclosure."

It is a familiar principle of securities law that when John Jones, an ordinary investor, sells 100 shares of $\mathrm{ABC}$, Inc. to Sam Smith, the public sale is an exempted transaction under section 4(1) of the 1933 Act, for the reason that Jones is not an "issuer," "underwriter," or "dealer" as those terms are used in section 2 of that Act. Accordingly, no registration of Jones' shares is necessary. Similariy, when Jones is a control person with respect to ABC, Inc., his sale to Smith may be an exempted transaction under sections $4(1), 3(a)(11)$ (intrastate offering), or 3(b) (Regulation A offering). ${ }^{10}$

8. See note 4 supra and accompanying text.

9. "The phrase 'improvement in ' 34 Act reporting' has at least three aspects: (1) more comprehensive reporting forms, (2) better administration and enforcement of requirements relating to the preparation and filing of such forms, and (3) better dissemination of the information contained in such forms." WHEAT REPORT 328.

10. Absent some exemption, secondary distributions by controlling shareholders who sell through brokers in the open market must be registered. But section $4(4)$ as implemented by rule 154 may permit a controlling person to dispose of a portion of his shares on the open market within certain limitations. In the Ira Haupt case approximately 93,000 shares were 
Absent these exemptions, however, Jones, whether he is a control person or even an ordinary seller, may have registration problems. These problems are largely due to uncertainty of the application of the Commission's rules and inconsistencies in their interpretation by the Commission's staff. The Wheat Report frankly admits the existence of this undesirable state of affairs and sceks to rectify it. In striving to dispel existing confusion concerning resale of securities acquired in private placements, the draftsmen of the Report have wisely proposed the adoption of objective standards and their application to secondary transactions by controlling and noncontrolling persons.

\section{The Non-CONTrol Shareholder: Existing Status}

The non-control shareholder who purchases his shares in a private offering is locked in. Indeed, this is one of the necessary criteria for availability of the section 4(2) exemption under which he purchased." But for how long is he locked in? There has never been an unequivocal answer to this question. "The length of time," observed the Commission, "is merely one evidentiary fact to be considered."'12 In short, no honest reply may be given to the understandable query of "How long do I have to hold?" Moreover, avenues of escape are usually, and properly, impeded. The attorney for the issuing company knows that if the private purchaser actually takes with a view to distribution he becomes a statutory underwriter and may subject the' company to loss of its private offering exemption. ${ }^{13}$ Accordingly, at the time of acquisition, he will usually insist upon an investment letter, a restrictive legend on the stock certificate, and the placing of a stop-transfer order against the

sold by controlling shareholders through a broker. The holding in that case was to the effect that a broker making a distribution for a controlling shareholder acts as an undenvriler and thus is not entitled to the exemption in section 4(4) for brokers' transactions. Ira Haupt, 23 S.E.C. 589 (1946). In the Haupl case the Commission took the position that section 4(4) was intended to distinguish between "trading" (exempt) and "distribution" (non-exempt) transactions. But the Haupt case left unanswered the question of when a broker was acting as a broker and when he was acting as an underwriter. It was for this reason that rule 154 was adopted. See SEC Securities Act Release No. 4818 (Jan'. 21, 1968); SEC Securities Act Release No. 4669 (Feb. 17, 1964).

11. See note 7 supra.

12. SEC Securities Act Release No. 4552 (Nov. 6, 1962). "Or course, the longer the period of retention, the more persuasive would be the argument that the resale is not at variance with an original investment intent . . . Id.

13. See note 7 supra. 
shares. Even after the passage of an appreciable period of time, absent an agreement with the company to register his shares, the private purchaser may not resell at the current market price unless he can find his own exemption and unless counsel for the company agrees that such an exemption is available. If he cannot convince company counsel of the availability of an exemption, he may nevertheless seek to obtain a no-action letter from the Commission. Failing to obtain a no-action letter, he is faced with the Hobson's choice of holding his shares for an additional indefinite period or selling them at a sacrifice to another private purchaser. The prospective purchaser of "letter stock" knows that he will be locked in for an uncertain period of time. Moreover, he cannot "tack" the length of time his seller held with that of his own; the holding period starts to run again. All this adds up to a substantial discount from the current market price when the private purchaser resells. ${ }^{14}$ But of even greater significance from an economic standpoint, the uncertainty surrounding the marketability status of shares purchased in private placements may lead to an unwillingness to supply venture capital to new enterprises. One who gets in on the ground floor may find himself in the cellar rather than in the penthouse. The game may not be worth the candle. But the point is that it should be; there is no sound reason why seed money cannot be supplied with the assurance that the shares given in exchange will appreciate in value if the company prospers and, more important, that the supplier of such venture capital can turn such shares into dollar bills at a predetermined time. This desirable result can and should be accomplished within the existing framework of federal securities regulation without sacrificing investor protection.

\section{The Non-control Shareholder and Proposed Reforms}

The Wheat Report proposals would improve the status of the non-control shareholder who acquires shares in a private offering in two principal respects: a definite holding period is established and a specific manner of resale is prescribed. ${ }^{15}$ ln this connection, however,

14. "[D]iscounts have been running from $35 \%$ to $50 \%$ in many instances . . . Indeed, the Securities and Exchange Commission, noting the illiquidity of unregistered shares, recently clamped a $10 \%$ lid on the amount open-end mutual funds - those that must stand ready to redeem their shares-may hold." The Wall St. Journal, Nov. 18, 1969, at 1, col. 6. See also Fund of Letters, Inc., SEC Registration No. 2-28515 (1968).

15. See WheAt RePORT 189-205. 
both the length of the holding period and the manner of resale are largely dependent upon whether the acquired shares are those of a company subject to the registration and reporting requirements of the 1934 Act. ${ }^{\text {16 }}$ As indicated previously, this distinction is based on the premise that purchasers of securities in a reporting company have current information available to them and thus have a better opportunity to make an informed investment decision. ${ }^{17}$

\section{The Non-control Shareholder's Status in a Reporting Company}

Suppose that John Jones purchases his securities in a private offering from $\mathrm{C}$ Corporation, a reporting company. ${ }^{18}$ The Wheat Report's proposed rules would permit him to sell these securities without registration after one year in limited quantities at specified times. ${ }^{19}$ More particularly, if Jones has not purchased any other $\mathrm{C}$ Corporation shares in a private offering during that year, he may sell under what are substantially the conditions provided in existing rule 154 , the so-called "one percent rule."20

An analysis of the reasons behind the proposed rules permitting limited sales of Jones' shares reveals, first, that those shares would be "restricted securities"-securities acquired from the company or a control person "in a transaction or chain of transactions none of which was a public offering . . . ."21 Second, when Jones sells his shares of C Corporation to Smith, he is not engaged in a "distribution" within the meaning of the proposed rules. ${ }^{22}$ ln sum, although Jones, a non-control shareholder in a reporting company, holds restricted securities even after the running of the one-year period, he is not engaged in a distribution if he sells in unsolicited brokerage transactions under a "one percent" limitation in any sixmonth period. ${ }^{23}$

\footnotetext{
16. See note 3 supra and accompanying text.

17. See note 8 supra and accompanying text.

18. See proposed rule 164. The proposed rules are contained in SEC Securities Act Release No. 4997 (Sept. 15, 1969).

19. Proposed rule 162(a) \& (c).

20. Id.

21. Proposed rule 161(a).

22. Proposed rule 162(a).

23. See WheAt RePORT 230-32 a.62. Futhermore, Jones may sell in successive six-month periods. Id. at 230. Proposed rule 162 should be read in conjunction with proposed rule 160 (underwriters) and proposed rule 163 (providing in effect that only securities of those companies on the "qualified list" may be publicly sold in limited quantities pursuant to proposed rule 162). It should also be noted that Jones has not privately purchased any other
} 
Why, one may ask, should Jones not be permitted to sell all of his shares after one year? If Jones holds stock in a company with a large number of shares issued and outstanding, the question may be academic, for in all probability he can sell all of his holdings in the first six-month period by selling one percent of the company's outstanding shares. But suppose that there is a relatively small number of shares outstanding. Now he may be unable to sell out for a protracted period of time. Or suppose that he does not want to sell at the end of one year because of a falling market. In short, why should non-control shareholders be subjected to such risks and penalties? After all, under the "improved reporting requirements" advocated by the Report, current information on the company would be available to prospective purchasers. That, coupled with the fact that in most instances the non-control shareholder wishes to dispose of a relatively small amount of shares, means that the proposed rules might place an undue burden on small shareholders when investor protection is not jeopardized. It is submitted that it would be preferable to permit the non-control shareholder to sell all of his shares at the end of a specified but reasonably short time; for example, the holding period could be increased to two years.

\section{The Non-control Shareholder's Status in a Non-reporting Company}

Assume that Jones is a non-control shareholder of $\mathrm{C}$ Corporation, a company not subject to the reporting requirements of the 1934 Act. The proposed rules would require him to hold for five consecutive years during each of which years $C$ Corporation has had gross revenues from its operations of at least $\$ 250,000$ but is not subject to the reporting requirements during that time. If at the end of the five-year period Jones has not privately purchased any other C Corporation shares, he is free to sell all of his securities without registration. ${ }^{24}$

C Corporation shares during the one-year holding period. Otherwise, he could evade the one percent limitation by commingling successive purchases. In effect, then, the proposed rules would retain the "fungibility" doctrine in this respect. Finally, "tacking" is permitted where Jones acquires his restricted securities as the result of a death, bona fide gift, pledge, stock dividend, stock split, or recapitalization. Proposed rule 162(c) (3)-(5).

24. Proposed rule 161(b) provides that securities cease to be restricted after such five-year period. Moreover, since Jones is not disposing of a restricted security, he cannot be an "underwriter" within the meaning of proposed rule 160.

Economic implications merit examination when "restricted securities" cease to be restricted, whether the prospective seller is a controlling or a non-controlling person. As 
Some questions immediately come to mind. Why was the longer five-year period selected? In other words, why should the fact that Jones is a shareholder in a non-reporting company require him to hold his shares for an additional four years before he is free to sell in the open market without registration? The obvious implication is that in the case of a non-reporting company Jones' purchaser lacks the protection of accessible information. Indeed, throughout the Report sharp distinctions have been drawn between reporting and non-reporting companies. ${ }^{25}$ In view of this fact, one is tempted to predict that many companies, in order to benefit all of their shareholders, will voluntarily become reporting companies even though they are not subject to the reporting requirements. In this connection, the 1934 Act provides that such companies may become reporting companies if they elect to do so, ${ }^{26}$ a process involving the filing of form 10, a relatively uncomplicated item-and-answer document. By this simple expedient the distinctions, and attendant disadvantages, can be avoided. But, after all, this is probably one of the real reasons underlying the Report's distinction: more companies will find it advantageous to become reporting companies; consequently, more information will become available to investors in the trading markets.

It will be recalled that securities do not automatically cease to be "restricted securities" after five years. Proposed rule 161 (b) also requires minimum annual gross revenues from operations of $\$ 250,000$ during each of those five years. This requirement may be criticized on the ground that even a successful corner drugstore may produce $\$ 250,000$ in yearly gross revenues, but of course the reason for the requirement is to prevent evasion of the rule through the use of a "shell" corporation" and thus to ensure that the company has had a bona fide operating business during the holding period. ${ }^{28}$ In addition, the gross revenue qualification has been criticized in that

previously pointed out, restricted shares now sell at substantial discounts in the open market. See note 14 supra and accompanying text. But as the shares become "seasoned" and the time for cessation of the restriction approaches, the discount should lessen accordingly, for prospective purchasers will know that the shares will soon become freely tradeable at the same price as other shares of the company already being traded on the open market.

25. See, e.g., WheAT REPORT 182-83, 206-15.

26. "Any issuer may register any class of equity security not required to be registered ..." Securities Exchange Act \& 12(g)(1), 15 U.S.C. \& 78/(g)(1) (1964).

27. See SEC Securities Act Release No. 4982 (July 2, 1969).

28. WheAT REPORT 203. 
a company's failure to meet the minimum figure may not be "compatible with any sound theory of statutory interpretation of the term "distribution." "29

\section{Status of the Controlling Person in Reporting and Non- reporting Companies at Present and Under the Proposed RULES}

It is a fundamental principle of securities regulation that, unless some exemption is available, shares owned by a person in a control relationship with the company must be registered prior to sale. ${ }^{30}$ The last sentence of section 2(11) of the 1933 Act contains the following language: "the term 'issuer' shall include, in addition to an issuer, any person directly or indirectly controlling or controlled by the issuer, or any person under direct or indirect common control with the issuer." 31 Pursuant to this provision, a person in a control relationship with an issuer is an issuer but solely for the purpose of making an "underwriter" persons who purchase from or sell for such "issuer" in connection with a distribution. ${ }^{32}$ Furthermore, a broker who sells for a controlling person in connection with a distribution is acting as an underwriter rather than as a broker. Consequently, the sales on behalf of the controlling person are not "brokers' transactions" and, therefore, are not exempted under section $4(4)$ and rule 154 promulgated thereunder. ${ }^{33}$ Thus, an investment banker who arranges with a controlling person for a

29. Throop, Federal Regulation of Securities Committee Comments on the Wheat Report, 25 Bus. LAw. 39, 48 (1969). "I cannot believe that an effective rule could not be drawn which would make the five-year cut-off unavailable where the alleged private placement is shown to be merely the initial step in a planned ultimate public distribution." Id. at 49.

30. See, e.g., Skiatron Electronics \& Television Corp., 40 S.E.C. 236 (1960); S.T. Jackson \& Co., 36 S.E.C. 631 (1950).

31. Securities Act $\S 2(11), 15$ U.S.C. $\S 77 b(11)$ (1964).

32. As indicated, this provision is limited to the purpose of defining an underwriter. Thus, although a person who purchases securities from one controlling or controlled by the issuer with a view to distribution will be an underwriter, the control person is not an issuer for the purpose of an exemption under section $3(a)(1)$ or section $4(2)$ or for the purpose of signing a registration statement. Similarly, if the person in control is a corporation, sales by its officers and directors or agents performing similar functions would be sales by the corporation and no underwriter would be involved. However, a person employed by the controlling corporation for the special purpose of effecting the distribution would be considered an underwriter. See American Gyro Corp., I S.E.C. 83, 93 (1935); rule 152A, Securities Act of 1933, 17 C.F.R. $\$ 230.152 \mathrm{a}$ (1970); SEC Securities Act Release No. 4470 (Mar. 22, 1962) (sale of fractional shares).

33. Rule 154, Securities Act of 1933, 17 C.F.R. $\$ 230.154$ (1970). 
public sale of securities is an underwriter. Additionally, if the securities are not registered, the broker will have violated the registration provisions of section 5 , and the controlling person will have been exposed to liability under the federal statute prohibiting aiding and abetting. ${ }^{34}$ But, despite the principles set forth in the foregoing discussion, the controlling person may have avenues of escape open to him. ${ }^{35}$

Under the rules proposed by the Wheat Report, a person's status with respect to the public sale of securities acquired in a private transaction may be largely dependent upon whether he is a controlling person. The concept of control has given rise to one of the most troublesome aspects of the entire field of securities regulation. The 1933 Act contains no meaningful definition of "control."3s The very fact that the term has caused such confusion in the legal and business communities would seem to have warranted a thorough treatment of the matter in the Wheat Report. Therefore it is disappointing that the draftsmen devote only five pages to a discussion of this problem. ${ }^{37}$ But what is even more disappointing is the negative approach used by the draftsmen in their attempt to find a workable solution. In effect, they have proposed a rule that attempts to define control as used in section $2(11)$ by specifying persons who are not to be considered as in control of the issuing corporation..$^{38}$ Although a detailed treatment of the concept of

34. 18 U.S.C. \& 2(b) (1964). Apparently one situation where it may make a difference whether the controlling person has violated section 5 himself or has aided and abelted its violation is where unusual circumstances make it more advantageous to proceed against the controlling person alone without joining the broker-underwriter. See United States v. Wolfson, 405 F.2d 779 (2d Cir. 1968), cert. denied, 394 U.S. 946 (1969).

35. Private placements by the control person (section 4(1)); the intrastate exemption (section 3(a)(1I)); Regulation A (\$100,000 each 12 months, or one of the other regulations under section 3(b)); section 4(1) as the result of the "brokers' transactions" exemption under section $4(4)$, in the sense that the selling control shareholder is indirectly protected by rule 154 in the event that no distribution is in progress; rules 133(d) and (e) (securities acquired in business combinations).

36. Rule 405, Securities Act of 1933: "The term 'control' (including the terms 'controlling', 'controlled by', and 'under common control with') means the possession, direct or indirect, of the power to direct or cause the direction of the management and policies of a person, whether througb the ownership of voting securities, by contract or otherwise." 17 C.F.R. \& 230.405 (1970). See also rule 410, Securities Act of 1933 (providing for existence of disclaimer of control), 17 C.F.R. $\$ 230.410$ (1970). These rules serve as little more than general guidelines to the meaning of the term in actual situations.

37. WHEAT REPORT 158-59, 245-47.

38. WhEAT REPORT app. VI-1, at 7 (proposed rule 160). In fairness it should be stated that a note to this rule contains the following language: "This rule is not intended to imply that 
control is beyond the scope of this article, ${ }^{39}$ the writer is aware that the existence of control may be dependent upon share ownership, family and business ties, contractual relationships, and a host of other factors. ${ }^{40}$ Moreover, it may be difficult to list meaningful criteria in objective terms. ${ }^{41}$ However, it is submitted that the difficulty is not insurmountable. A logical argument can be made for establishing control criteria in an affirmative manner, depending upon such factors as the number of shares outstanding, the character of trading in those shares, and the identity of the trader. Different and realistic limitations could then be applied to each criterion. In short, there is no convincing reason why control should not be stated in affirmative as well as objective terms. Such an approach would provide both certainty and flexibility. In this connection it is noteworthy that the Commission has not seen fit to implement the Report in the complicated and negative manner suggested by its draftsmen."2

Assuming that a control relationship does exist between Jones and $C$ Corporation, a reporting company, the proposed rules would permit him to sell his shares acquired in a private transaction under the same conditions as a non-controlling person..$^{43}$ In short, he may sell within the conditions of the "one percent" rule after holding for one year. Even this holding period does not apply if Jones acquired his shares in a public offering or in the trading markets. ${ }^{44}$ This proposed rule makes sense, and it is hoped that the Commission will see fit to adopt it in its present form. ${ }^{45^{\circ}}$

What does not make sense, however, is the Report's and the Commission's proposed treatment of Jones as a controlling person

persons who do not come within its terms are for that reason deemed to be 'in control' of an issuer." Id.

39. See generally C. IsRaels, supra note 7; Enstam * Kamen, Control and the Institutional Investor, 23 Bus. Law. 289 (1968); Sommer, Who's "In Control"?-S.E.C., 21 Bus. LAw. 559 (1966).

40. See, e.g., S.T. Jackson \& Co., 36 S.E.C. 631 (1950).

41. "It would be difficult if not impossible to enumerate or to anticipate the many ways in which actual control may be exerted." H.R. REP. No. 1383, 73d Cong., 2d Sess. 26 (1934).

42. Compare proposed rule 160 with WhEAT REPORT app. VI-1, at 7 (proposed rule 160).

43. See notes 20-23 supra and accompanying text.

44. "Except in [this] one respect, controlling persons and holders of 'restricted securities' of reporting companies are on much the same footing. There is a difference between them only if the controlling person acquired his securities in a public offering or in the trading markets. In that case . . . the securities are not 'restricted securities' and the holding period requirement in rule 162(b) does not apply." WHEAT REPORT 229-30.

45. See SEC Securities Act Release No. 4997, at 17-19 (Sept. 15, 1967). 
when $C$ Corporation is a non-reporting company. Under the proposed rules, absent registration or some exemption, ${ }^{46}$ Jones can never sell through a broker his securities acquired in a private transaction as long as he remains a controlling person and as long as $\mathrm{C}$ Corporation, or its successor, remains a non-reporting company. ${ }^{47}$ It is at once apparent that in at least one respect the proposed rules would put the controlling shareholder in a less advantageous position than he now enjoys. As indicated previously, existing rule 154 may be indirectly available to the controlling shareholder not engaged in a distribution to enable him to sell his securities on the open market through a broker within the limitations of the "one percent" rule..$^{48}$ Adoption of the proposed rules, however, would spell loss of this exemption.9 Does the distinction between reporting and non-reporting companies made by the Report and the Commission really justify this result? With respect to restraints on alienation, the draftsmen themselves had this to say: "Perpetual restraints on alienation have been viewed with disfavor and would create difficulties in the administration of the Act." ${ }^{50}$ One may quarrel, then, with the status of the controlling shareholder under the proposed rules on the ground that it is actually inconsistent with the intent of those rules.

It is probable that to avoid this onerous distinction controlling shareholders will cause their companies to become reporting companies voluntarily even though the statutory requirements are not present. ${ }^{51}$ Desirable as this may seem from the standpoint of expanded disclosure, it may mean that costs attendant to filing and reporting such as the expense of annual audits will be borne, at least indirectly, by minority shareholders who thus will receive less of the company's earnings in the form of dividends. It is submitted that existing rule 154 with its stringent limitations provides ample

46. See Whent Report 226-27; Holland, Public Sale of Control Stock and Private Investment Stock: The SEC's Proposed New Rules, 25 Bus. Law. 1027, 1032 (1970).

47. WhEAT REPORT 226-27. Presumably this result is reached because C Corporation is not on the "qualified list" as set forth in proposed rule 163 and therefore a public sale by Jones, absent some exemption, would involve a distribution within the meaning of section $2(11)$ as implemented by proposed rule 162 .

48. See note 35 supra and accompanying text.

49. Proposed rule 164, which would replace existing rule 154, explicitly extends only to the "broker's part of the "brokers' transaction.' " The offeror's part of the transaction would not be exempt.

50. WHEAT REPORT 189.

51. See note 26 supra and accompanying text. 
protection for investors in the trading markets. The proposed rules are unduly harsh and unwarranted in this respect. ${ }^{52}$

\section{CONCLUSION}

Adoption of some of the recommendations proposed by that important segment of the Wheat Report dealing with private placements and secondary transactions may produce some harsh results that might have been avoided through more realistic thinking on the part of its draftsmen. But it is easy to criticize. One fact stands out in clear relief: the investor who acquires his shares in a private placement will know where he stands. No longer will he be in doubt concerning how long he must hold and under what conditions he is frce to sell on the open market without registration. For the first time in the Act's 37-year history there will be objective standards to guide him. This step forward, long overdue, may be counted as one of the chief legal and economic gains of the Report. In this respect, adoption of the Report's recommendations should represent a welcome innovation to members of the legal and financial communities.

52. With respect to disposition of shares by controlling persons, Congress has created an apparent loophole that is not generally known to the legal profession. Therc is a precept that the Commission follows which is not explicit in the $1933 \mathrm{Act}$, namely that the registration requirements of the Act do not go beyond sales of securities to the general public. Accordingly, a controlling person acting alone, that is without a broker, may sell his shares to the general public, and the Commission might be at a loss to regard any of his purchasers as underwriters. Put another way, if an offering is made directly by the person in control without the use of selling agents or dealers, it may be an offering by a person other than an issuer, underwriter, or dealer and thus be exempt. Applying these principles to the proposed rules, presumably a controlling person would be able to sell all of his shares directly to the public without registration. See Schulman, Book Review, 15 WAYNE L. Rev. 1374, 1379 n.19 (1969). Such a procedure, however, may be more theoretical than real, since it is unlikely that the controlling person would be able to sell a large amount of stock without the intervention of persons whom the Commission could label as underwriters. 
